$\begin{array}{rr}\text { FIT(8)ATOLOGI } & \text { Volume } 14, \text { Nomor } 1 \text {, Januari } 2018 \\ \text { I N D ON E S I A } & \text { Halaman } 7-14 \\ \text { ISSN: } 0215-7950 & \text { DOI: } 10.14692 / \text { jfi. } 14.1 .7\end{array}$

\title{
Perlakuan Udara Panas untuk Pengendalian Perkecambahan Spora Tilletia indica pada Gandum
}

\section{Air Heat Treatment to Suppress Sporulation of Tilletia indica on Wheat}

\author{
Nurul Dwi Handayani ${ }^{1 *}$, Taufan Tanto Setyawan' ${ }^{1}$, Salbiah $^{1}$, \\ Dono Wahyuno ${ }^{2}$, Meity Suradji Sinaga ${ }^{3}$ \\ ${ }^{1}$ Balai Uji Terap Teknik dan Metode Karantina Pertanian, Bekasi 17520 \\ ${ }^{2}$ Balai Penelitian Tanaman Rempah dan Obat, Bogor 16111 \\ ${ }^{3}$ Institut Pertanian Bogor, Bogor 16680
}

\begin{abstract}
ABSTRAK
Karnal bunt adalah penyakit pada gandum (Triticum aestivum) yang disebabkan cendawan Tilletia indica. Penyakit ini menjadi perhatian utama dalam perdagangan internasional karena dapat menurunkan kualitas gandum dan merupakan organisme pengganggu tumbuhan karantina yang belum terdapat di Indonesia. Biji gandum yang terinfeksi Tilletia spp. dapat menjadi pembawa teliospora. Penelitian bertujuan mendapatkan suhu dan lama paparan yang efektif untuk mengeliminasi Tilletia spp. yang terbawa biji gandum menggunakan perlakuan panas tanpa mengurangi kualitas gandum. Pengujian dilakukan secara in vitro, diawali dengan deteksi dan identifikasi Tilletia secara morfologi dilanjutkan uji viabilitas teliospora. Perlakuan udara panas menggunakan oven pada suhu $75,80,85^{\circ} \mathrm{C}$, dan kontrol $\left(28^{\circ} \mathrm{C}\right)$ selama 4 dan 6 jam dengan 3 ulangan. Hasil pengujian menunjukkan bahwa pemanasan biji gandum pada suhu $75{ }^{\circ} \mathrm{C}$ selama 4 jam dapat menekan perkecambahan teliospora sebesar $56.7-61.7 \%$ tanpa menurunkan kadar protein pada gandum.
\end{abstract}

Kata kunci: karnal bunt, organisme pengganggu tumbuhan karantina, teliospora, uji viabilitas

\begin{abstract}
Karnal bunt of wheat (Triticum aestivum) caused by Tilletia indica is a major concern in international trade because it can degrade quality significantly, and it is a quarantine pest for Indonesia. Tilletia infected seeds can be the source of fungal inoculum of other areas. The current research was aimed to determine the effectiveness of temperature and exposure time to control Tilletia using air heat treatment without reducing the quality of grain. The experiments were conducted in vitro, initiated by seed testing, including morphology-based detection and identification of Tilletia followed by a viability test of the seed. Air heat treatment was performed by adjusting the oven temperature at $75,80,85^{\circ} \mathrm{C}$ and $28{ }^{\circ} \mathrm{C}$ (control) for 4 and $6 \mathrm{hr}$ exposure time, each with three replications. The results showed that air heat treatment of the wheat at $75^{\circ} \mathrm{C}$ for $4 \mathrm{hr}$ was able to suppress teliospores germination of $56.7-61.7 \%$, without denature protein content of the wheat.
\end{abstract}

Key words: karnal bunt, teliospores, quarantine pest, viability test

*Alamat penulis korespondensi: Balai Uji Terap Teknik dan Metode Karantina Pertanian, Jalan Raya Kampung Utan-Setu, Desa Mekarwangi, Cikarang Barat-Bekasi, Jawa Barat-17520

Tel: 021-82611619, Faks : 021-82618923, Surel: nurul@buttmkp.org 


\section{PENDAHULUAN}

Gandum merupakan komoditas pangan alternatif yang strategis. Indonesia merupakan negara pengimpor gandum terbesar kedua di dunia setelah Mesir. Impor biji gandum selama tahun 2013 mencapai 6629 juta ton dan tahun 2014 mencapai 6689 juta ton. Gandum tersebut berasal dari negara Australia, Kanada, Amerika Serikat, India, Ukrainia, dan Rusia. Volume impor gandum yang tinggi menimbulkan risiko kemungkinan terbawanya organisme pengganggu tumbuhan karantina (OPTK) dalam biji gandum. Patogen pada gandum yang penting secara ekonomi ialah Tilletia indica, Fusarium spp., Ustilago nuda var. tritici, Clavibacter tritici, Anguina tritici, Septoria tritici, S. nodorum, $S$. avenae f. sp. triticea, Helminthosporium sativum, $H . \quad$ tritici-repentis, Alternaria triticina, F. nivale, Stagonospora nodorum, Claviceps purpurea, Xanthomonas campestris pv. Translucens (Majumder et al. 2013).

Tilletia indica pertama kali dilaporkan ditemukan di Karnal India (Mitra 1931) dan sekarang telah tersebar di berbagai negara seperti Pakistan, Iran, Irak, Meksiko dan Amerika Serikat (Warham 1986). Kombinasi suhu dan kelembapan di lapang penting untuk terjadinya epidemi $T$. indica, karena akan memengaruhi perkecambahan teliospora sebelum terjadi infeksi (Stein et al. 2005) tetapi suhu yang tinggi akan mematikan teliospora Tilletia (Khan et al. 2010). Perlakuan udara panas $\left(70{ }^{\circ} \mathrm{C}\right)$ dengan kelembapan relatif $(\mathrm{RH}) \quad 50 \%$ selama 240 menit atau $80{ }^{\circ} \mathrm{C}$ dengan $\mathrm{RH}$ di bawah $50 \%$ selama 40 menit dinyatakan efektif mengeliminasi $T$. caries sebesar $100 \%$ di Cina (Lei et al 2012). Di Indonesia, saat ini belum diketahui suhu dan waktu pada perlakuan udara panas yang efektif untuk mengendalikan Tilletia spp. yang terbawa pada gandum impor. Oleh karena itu, penelitian ini dilakukan untuk mendapatkan suhu dan lama paparan yang efektif untuk mengendalikan Tilletia spp. yang terbawa biji gandum tanpa mengurangi kualitas gandum.

\section{BAHAN DAN METODE}

\section{Deteksi dan identifikasi Cendawan Tilletia spp. pada biji gandum}

Penelitian diawali dengan mencari biji gandum ( $T$. aestivum) impor yang membawa teliospora Tilletia spp. Biji gandum yang terinfeksi Tilletia ditandai dengan adanya massa spora berwarna cokelat sampai hitam dan berbau busuk (Mansoori 2015). Keberadaan teliospora dideteksi menggunakan mikroskop dan dikumpulkan dengan cara pencucian benih (washing test). Sebanyak 50 g biji gandum dimasukkan ke dalam erlenmeyer $250 \mathrm{~mL}$ dan ditambahkan $0.01 \%$ larutan tween 20 dan $100 \mathrm{~mL}$ air destilasi. Erlenmeyer dikocok selama 3 menit dan larutannya disaring dengan kassa 2 lembar, dibilas menggunakan $20-50 \mathrm{~mL}$ air destilasi dan $0.01 \%$ tween 20 sebanyak 2 kali sampai bersih. Hasil saringan disaring kembali dengan menggunakan kertas Whatmann lalu dibilas air destilasi menggunakan botol semprot. Air bilasan tersebut dipindahkan ke dalam tabung mikro untuk disentrifugasi dengan kecepatan 3000 rpm selama 3 menit. Lapisan atas dibuang menggunakan pipet pasteur dan endapan ditambahkan air destilasi secukupnya kemudian diamati dengan mikroskop. Teliospora diidentifikasi secara morfologi berdasarkan karakteristik teliospora yang dibuat oleh Inman et al. (2003) untuk memastikan spesies Tilletia yang digunakan.

\section{Uji viabilitas teliospora Tilletia spp.}

Teliospora diuji viabilitasnya untuk memastikan bahwa teliospora yang digunakan masih aktif. Selain untuk mengetahui bentuk perkecambahan teliospora dan menentukan waktu pengamatan jumlah teliospora yang berkecambah setelah perlakuan pada uji in vitro. Uji viabilitas dilakukan dengan memasukkan 3 biji gandum yang terinfeksi Tilletia spp. ke dalam tabung yang berisi $1 \mathrm{~mL}$ air steril. Tabung tersebut dikocok menggunakan vorteks agar teliospora terlepas. Sebanyak $1 \mathrm{~mL}$ suspensi teliospora dituang 
pada $2 \%$ medium agar-agar air (EPPO 2007) dan diinkubasi pada suhu $4{ }^{\circ} \mathrm{C}$ selama 1 jam (Sinaga 2015, komunikasi pribadi), kemudian diinkubasi kembali pada suhu $28{ }^{\circ} \mathrm{C}$.

Pengamatan teliospora yang berkecambah dilakukan setiap hari hingga hari ke-7 dengan cara mengambil teliospora yang berada dalam medium agar-agar air kemudian diletakkan pada kaca objek dan diamati menggunakan mikroskop. Sebanyak 50 teliospora per hari dihitung persentase perkecambahannya dengan rumus:

$\%$ perkecambahan teliospora $=\frac{\mathrm{A}-\mathrm{B}}{\mathrm{B}} \times 100 \%$, dengan

A, persentase asal perkecambahan; dan B, persentase kecambah setelah perlakuan. Teliospora yang berkecambah dicirikan dengan adanya promiselium (tabung kecambah) berwarna jernih yang keluar dari teliospora.

\section{Uji in vitro perlakuan udara panas}

Uji in vitro dilakukan untuk mendapatkan suhu dan lama paparan efektif yang dapat mematikan teliospora Tilletia spp. pada gandum. Penelitian disusun menggunakan rancangan acak lengkap faktorial. Kombinasi dari perlakuan suhu sebagai faktor pertama dan lama paparan sebagai faktor kedua. Kisaran suhu yang digunakan ialah $75,80,85^{\circ} \mathrm{C}$, dan kontrol $\left(28^{\circ} \mathrm{C}\right)$. Lama paparannya ialah 4 dan 6 jam sehingga terdapat 8 kombinasi perlakuan. Percobaan ini diulang 3 kali sehingga terdapat 24 kombinasi perlakuan dan pada masingmasing kombinasi perlakuan disertakan $50 \mathrm{~g}$ biji gandum sehat sebagai pembanding.

Sebanyak 10 biji gandum sehat, yang tidak terinfeksi cendawan ditulari 1 biji gandum terinfeksi Tilletia dengan cara memasukkan biji-biji gandum tersebut ke dalam tabung reaksi dan ditambahi $5 \mathrm{~mL}$ akuades. Selanjutnya tabung berisi biji tersebut dikocok menggunakan vorteks dengan kecepatan $1000 \mathrm{rpm}$ selama 30 detik sehingga teliospora terlepas dan menempel pada biji gandum yang sehat. Biji gandum yang telah diinokulasi dimasukkan ke dalam cawan petri dan diberi perlakuan udara panas oven bersama $50 \mathrm{~g}$ biji gandum yang sehat (Irena et al. 2013). Peubah yang diamati ialah jumlah teliospora yang berkecambah dan kadar protein pada setiap perlakuan. Kadar protein diukur menggunakan metode Kjeldahl melalui tahapan destruksi, destilasi dan titrasi dengan alat uji Protein Foss Tecator Kjeltec 8400 dan Kjeltech BUCHI. Data pengaruh perlakuan (kombinasi suhu dan lama paparan) diuji dengan analisis ragam (anova). Uji lanjut untuk melihat perbedaan antarperlakuan digunakan uji Duncan pada $\alpha$ $5 \%$ dengan program SAS.

\section{HASIL}

\section{Deteksi dan identifikasi Tilletia spp. pada biji gandum}

Pada biji gandum impor yang diamati, terdapat gejala bercak warna hitam di daerah suture (garis pemisah kotiledon) dan struktur mirip pasir warna hitam yang merupakan massa teliospora Tilletia (Gambar 1a dan 1b). Teliospora berdiameter 28.8-34.0 $\mu \mathrm{m}$ dan berwarna cokelat muda, cokelat tua hingga hitam. Tinggi ornamen teliospora ialah 1.5-5.0 $\mu \mathrm{m}$ yang dilapisi selubung hialin (transparan). Ornamen pada bagian luar permukaan spora terlihat seperti otak (cerebriform) (Gambar 1c) dan tersusun teratur seperti duri yang terpotong (Gambar 1d). Berdasarkan karakteristik ukuran, bentuk ornamen dan model perkecambahan maka cendawan tersebut diidentifikasi sebagai Tilletia indica sesuai dengan kunci identifikasi Inman et al. (2003).

\section{Viabilitas Teliospora Tilletia spp.}

Viabilitas teliospora mencapai $100 \%$ pada hari ke-3 dan ke-4 (Gambar 2). Teliospora yang berkecambah dicirikan dengan adanya promiselium (tabung kecambah) yang keluar dari spora (Gambar 3). Berdasarkan kondisi tersebut, pengamatan teliospora pada saat perlakuan udara panas dilakukan pada hari ke-4.

\section{Perlakuan Udara Panas Tilletia spp. secara in vitro}

Hasil anova menunjukkan bahwa tidak ada interaksi antara faktor suhu dan lama paparan udara panas terhadap perkecambahan teliospora T. indica (Gambar 4) sehingga 


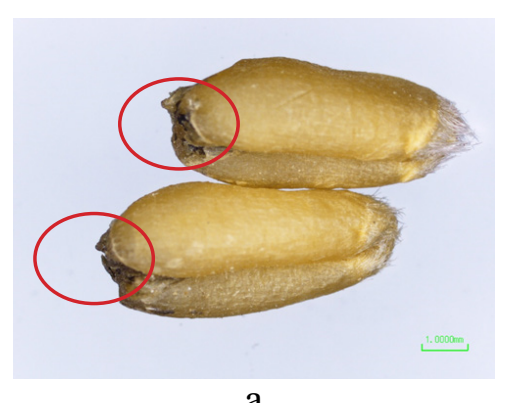

a

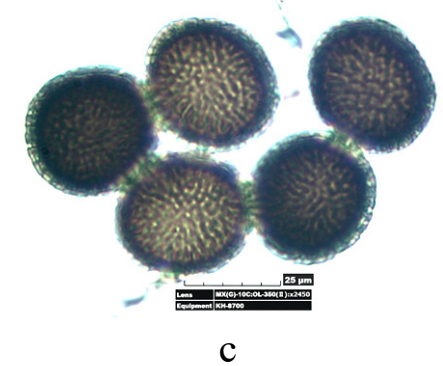

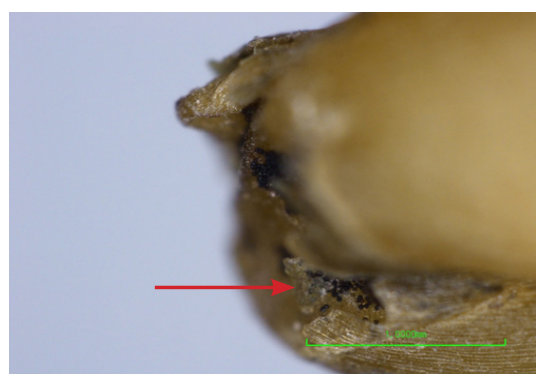

b

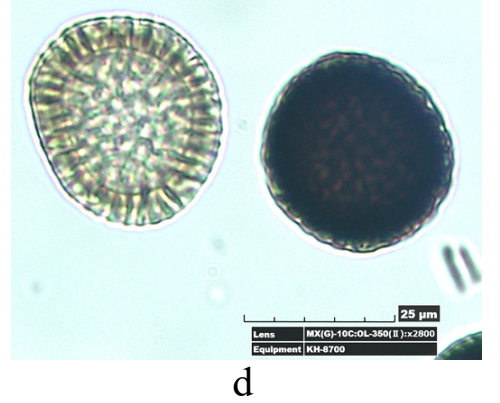

Gambar 1 Biji gandum dan Tilletia indica. a, Gejala penyakit karnal bunt; b, Kumpulan teliospora pada daerah suture $(\rightarrow)$; c, Ukuran dan warna serta; d, Ornamentasi teliospora.

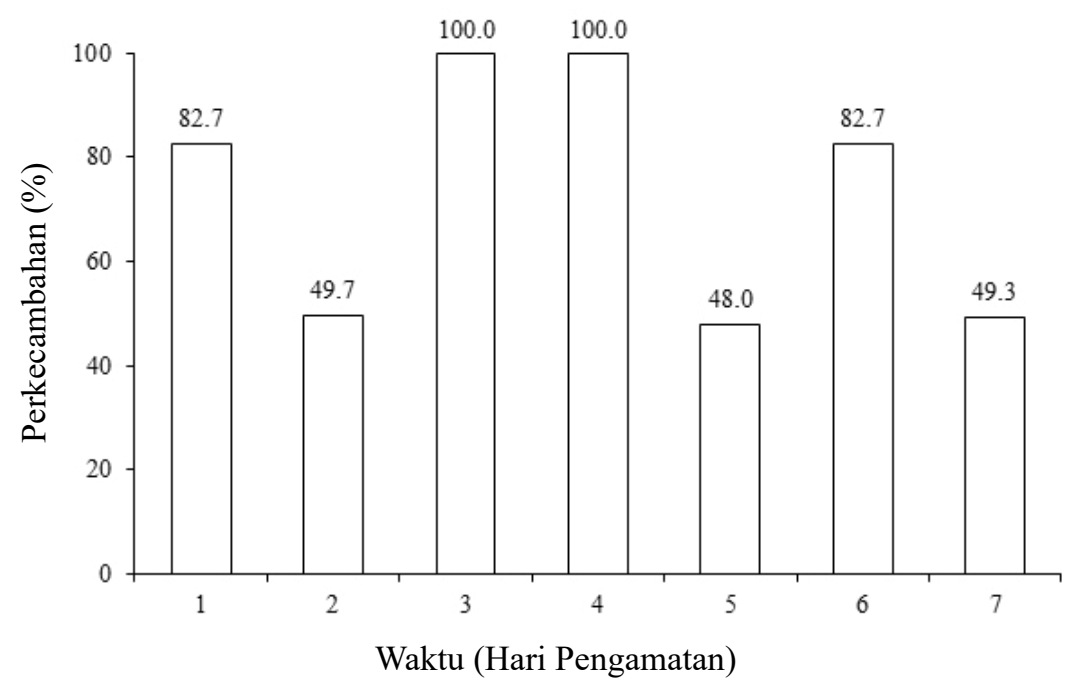

Gambar 2 Tingkat perkecambahan teliospora Tilletia indica pada hari ke-1 sampai dengan hari ke-7.

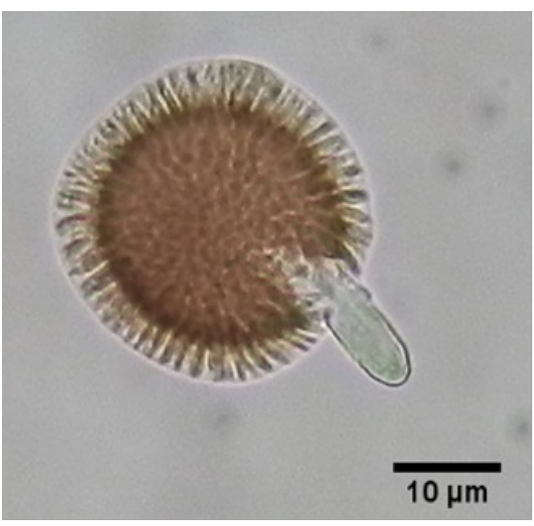

a

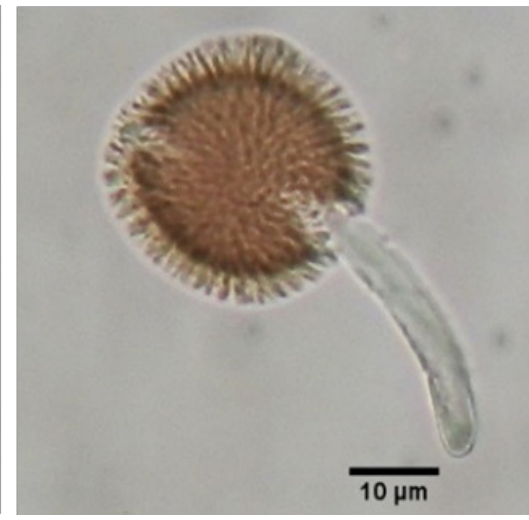

$\mathrm{b}$

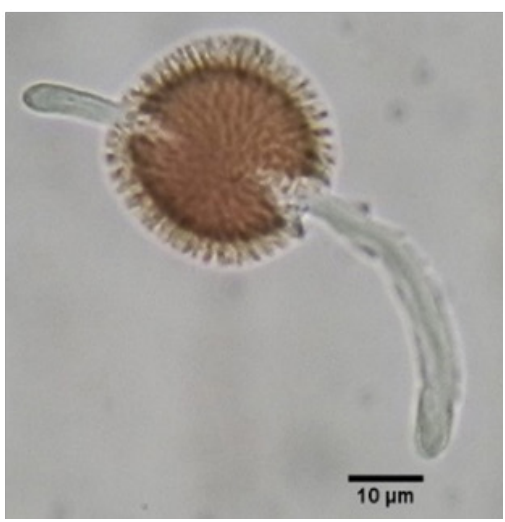

c

Gambar 3 Perkembangan bentuk kecambah teliospora Tilletia indica sebelum diberi perlakuan udara panas. a, Menit pertama; b, Menit ketiga; c, Menit kelima. 
analisis lebih lanjut dilakukan pada masingmasing faktor. Teliospora masih mampu berkecambah setelah perlakuan udara panas selama 4 dan 6 jam (Gambar 5). Pada semua uji yang dilakukan, tidak ditemukan adanya bentuk perkecambahan yang berbeda antara teliospora yang telah diberi perlakuan udara panas dengan yang terdapat pada kontrol, yang berarti bahwa teliospora tersebut bersifat infektif.

Pengaruh faktor suhu pada perlakuan udara panas mengakibatkan jumlah perkecambahan teliospora menurun tetapi belum mampu menekan hingga 100\%. Hasil perlakuan udara panas pada uji in vitro, perlakuan suhu menurunkan jumlah perkecambahan teliospora secara nyata sebesar $56.7-61.7 \%$ dibandingkan dengan perkecambahan pada kontrol (40\%) (Tabel 1).

\section{Kadar protein gandum}

Kadar protein gandum setelah perlakuan dibandingkan dengan kontrol menunjukkan tidak ada penurunan dari kadar protein (Tabel 1).

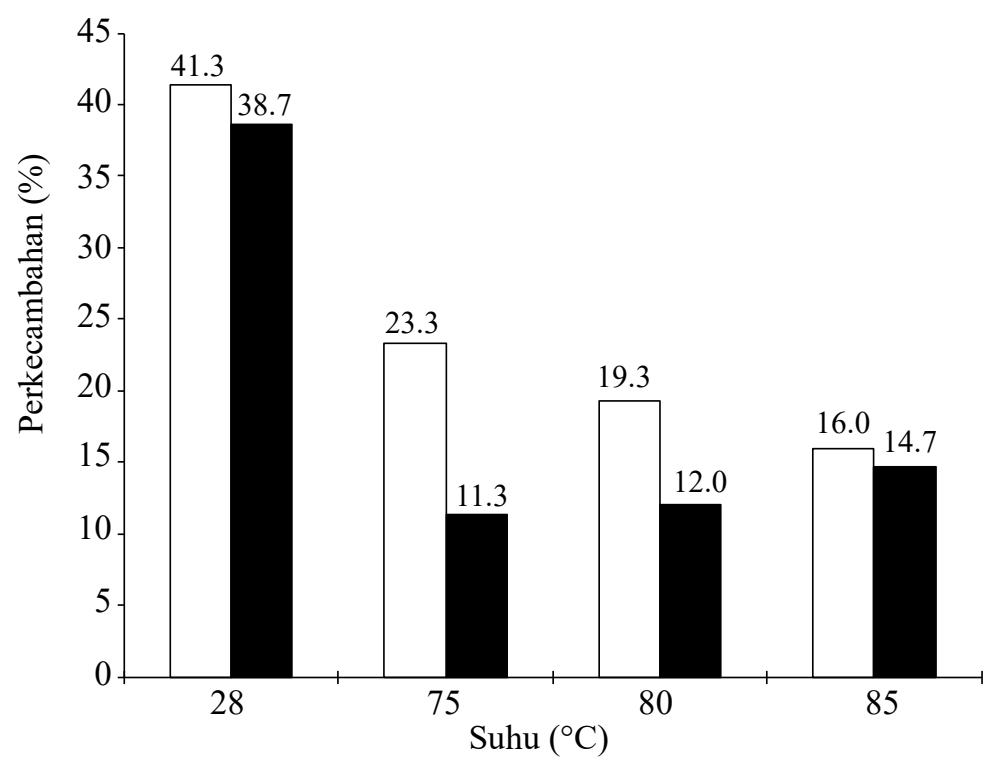

Gambar 4 Kombinasi perlakuan suhu dan waktu pemanasan ( $\square, 4$ jam; dan $\mathbf{\square}, 6$ jam) terhadap tingkat perkecambahan teliospora Tilletia indica yang berkecambah.

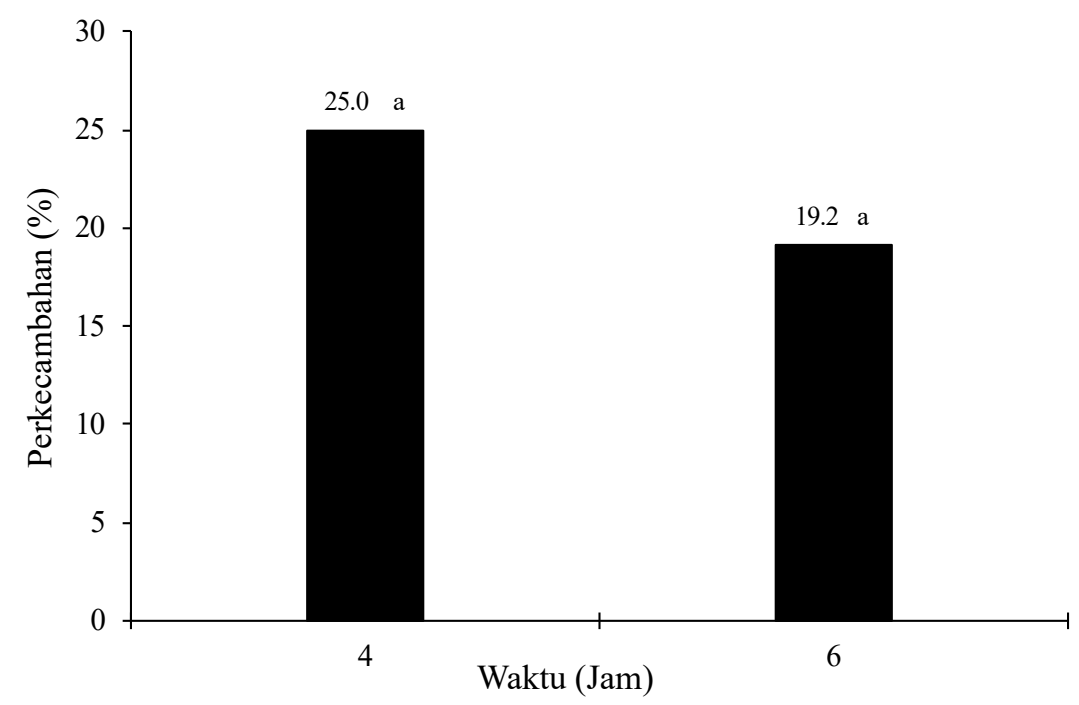

Gambar 5 Lama waktu pemanasan terhadap tingkat perkecambahan teliospora pada uji in vitro. Angka yang diikuti huruf yang sama menunjukkan tidak berbeda nyata berdasarkan uji DMRT pada $\alpha 5 \%$. 
Tabel 1 Perkecambahan teliospora (\%) dan kadar protein gandum (\%) pada uji in vitro dengan berbagai suhu.

\begin{tabular}{ccc}
\hline $\begin{array}{c}\text { Suhu } \\
\left({ }^{\circ} \mathrm{C}\right)\end{array}$ & $\begin{array}{c}\text { Perkecambahan } \\
(\%)\end{array}$ & $\begin{array}{c}\text { Kadar protein } \\
(\%)\end{array}$ \\
\hline 28 & $40.00 \mathrm{a}$ & 11.22 \\
75 & $17.33 \mathrm{~b}$ & 12.00 \\
80 & $15.67 \mathrm{~b}$ & 11.85 \\
85 & $15.33 \mathrm{~b}$ & $-*$ \\
109 & - & 11.05 \\
\hline
\end{tabular}

* Tidak dilakukan pengamatan.

Angka yang diikuti huruf yang sama menunjukkan tidak berbeda nyata berdasarkan uji DMRT pada $\alpha 5 \%$.

\section{PEMBAHASAN}

Tilletia yang terbawa pada gandum impor mempunyai teliospora dengan ukuran dan warna yang diidentifikasi sebagai $T$. indica. Ukuran diameter berada dalam kisaran yang dilaporkan oleh (EPPO 2013), yaitu 22-64 $\mu \mathrm{m}$ dengan rata-rata 35-41 $\mu \mathrm{m}$. Cendawan $T$. indica termasuk dalam kategori OPTK A1 (Permentan 2015) dan teliosporanya dapat terbawa gandum yang diimpor. Oleh karena itu $T$. indica harus dicegah masuk ke dalam wilayah Indonesia.

Teliospora yang berkecambah akan menghasilkan sporidia dan apabila kondisi lingkungan sesuai, sporidia akan membentuk tabung kecambah. Sporidia yang terbawa angin akan menginfeksi dan menyebabkan penyakit karnal bunt jika menemukan tanaman inang yang sesuai dan kondisi lingkungan mendukung. Secara alami, teliospora Tilletia yang ada di tanah atau biji gandum yang terinfeksi akan melalui masa dorman selama musim dingin dan berkecambah di saat tanaman gandum mulai tumbuh di musim semi (Weichuan dan Gui-ming 2010). Suhu yang ideal bagi munculnya biji gandum juga ideal bagi perkecambahan teliospora Tilletia (Cunfer et al. 1997). Inkubasi pada medium agar-agar air dalam inkubator bersuhu $4{ }^{\circ} \mathrm{C}$ selama 1 jam dapat menstimulasi teliospora Tilletia berkecambah. Hal serupa juga dilaporkan Bonde dan Nester (1999) yang mendapatkan perkecambahan teliospora $T$. indica tertinggi terjadi pada hari ke-3 sampai ke-14 bergantung pada perlakuan yang diberikan. Teliospora T. indica yang sudah disimpan pada suhu rendah mampu berkecambah dan segera menghasilkan sporidia sekunder dalam waktu singkat setelah diinkubasi pada suhu $20-22{ }^{\circ} \mathrm{C}$, dengan kelambapan 70\% (Mansoori 2015).

Uji perlakuan udara panas secara in vitro pada suhu 75,80 dan $85^{\circ} \mathrm{C}$ dengan waktu papar 4 dan 6 jam belum mampu mengeliminasi $T$. indica hingga $100 \%$ pada gandum. Pemaparan pada suhu $85^{\circ} \mathrm{C}$ selama 4 maupun 6 jam masih menghasilkan teliospora yang berkecambah antara $56.7-61.7 \%$. Selain berfungsi sebagai alat penyebaran yang efisien, teliospora juga menjaga keberlangsungan hidup pada kondisi tidak menguntungkan. Dinding teliospora Tilletia yang tebal memungkinkan cendawan ini bertahan pada kondisi kering, paparan sinar matahari yang berlebih, suhu ekstrem dan bahkan menjadikannya tahan terhadap fungisida. Piepenbring et al. (1998) mendapatkan bahwa di dalam kelompok jamur api (smut), tipe Tilletia dan Ustilago mempunyai eksopsora yang paling tebal dibandingkan dengan Microbotryum maupun Enthorrhiza. Dinding teliospora $T$. indica terdiri atas tiga lapis: endosporium, episporium dan perisporium. Dinding tebal yang berbilahbilah terdapat pada endosporium dan tonjolantonjolan yang keras dan tebal pada episporium (Sharma dan Kumari 2017).

Perlakuan udara panas secara in vitro pada suhu $85{ }^{\circ} \mathrm{C}$ selama 4 jam belum efektif untuk eliminasi $T$. indica pada gandum sehingga perlu dilakukan pengujian pada suhu yang lebih tinggi dengan periode paparan yang lebih lama, atau kombinasi beberapa perlakuan lainnya. Hasil penelitian ini berbeda dengan yang diperoleh oleh Lei et al. (2012) 
yang menggunakan T. caries. Perbedaan hasil yang diperoleh mungkin disebabkan adanya perbedaan spesies Tilletia yang diuji atau kelembapan udara saat perlakuan panas diberikan. Waldow dan Jahn (2007) melaporkan bahwa perlakuan perendaman gandum ke dalam air panas $\left(52-53^{\circ} \mathrm{C}\right)$ selama 10 menit dapat menekan laju infeksi dan kejadian common bunt pada gandum akibat $T$. tritici. Sharma dan Kumari (2017) menyatakan bahwa perendaman biji gandum ke dalam air panas, penjemuran, dan fungisida efektif mematikan teliospora $T$. indica, tetapi cara ini tidak efektif selama sumberinokulum selaluada di tanah. Populasi Sphacelotheca-penyebab gosong pada jagung-akan turun seiring dengan meningkatnya suhu dan kelembapan tanah (Matyac dan Kommedahl 1985). Bhuiyan et al. (2009) mendapatkan viabilitas teliospora Ustilago scitaminea penyebab penyakit gosong pada tebu menurun apabila berada di lingkungan yang lembap di dalam tanah dibandingkan dengan berada di tempat yang kering. Efektivitas perlakuan panas perlu ditingkatkan dengan cara melalukan kombinasi perlakuan, seperti peningkatan kelembapan udara atau perpanjangan waktu pemanasan. Kadar protein gandum pada perlakuan udara panas dengan suhu $109^{\circ} \mathrm{C}$ selama 4 jam masih memenuhi standar (CODEX 2001).

Perlakuan udara panas pada gandum menggunakan suhu 75,80 , dan $85^{\circ} \mathrm{C}$ selama 4 maupun 6 jam menekan perkecambahan teliospora T. indica. Pemanasan gandum selama 4 jam pada suhu $75{ }^{\circ} \mathrm{C}$ tidak menurunkan kadar protein pada gandum.

\section{UCAPAN TERIMA KASIH}

Penulis mengucapkan terima kasih kepada Balai Uji Terap Teknik dan Metode Karantina Pertanian-Badan Karantina Pertanian yang telah memberikan dana penelitian. Terima kasih juga kami sampaikan kepada Balai Besar Uji Standar Karantina Pertanian dan Balai Karantina Pertanian Kelas II Cilegon atas dukungan teknis yang telah diberikan kepada kami.

\section{DAFTAR PUSTAKA}

Bhuiyan S, Croft BJ, Cox MC. 2009. Survival of sugarcane smut teliospores under south east Queensland conditions. Proc Aust Sugar Cane Technol. 31:135-144.

Bonde MR, Nester SE. 1999. Comparison of effects of acidic electrolyzed water and $\mathrm{NaOCl}$ on Tilletia indica teliospore germination. Plant Dis. 83(7):627632. DOI: https://doi.org/10.1094/ PDIS.1999.83.7.627.

CODEX. 2001. Codex standar for wheat protein product including wheat gluten. Codex stan 163-1987, Rev-2001.

Cunfer BM, Deuce GK, Padgett GB, Miller AE. 1997. Karnal Bunt. Tilletia (Neovossia) indica. Los Angeles (US): USDA-APHIS-PPQ.

[EPPO] European Plant Protection Organization. 2007. Tilletia indica. Bulletin EPPO. 37:503-520.http:// onlinelibrary.wiley.com/doi/10.1111/ j.1365-2338.2007.01158.x/epdf. [diakses 17 Feb2015]. DOI: https://doi.org/10.1111/ j.1365-2338.2007.01158.x.

[EPPO] European Plant Protection Organization. 2013. Data sheets on quarantine pests : Tilletia indica. http:// www.eppo.int/QUARANTINE/fungi / Tilletia_indica/NEOVIN_ds.pdf [diakses 10 Jun 2013].

Inman AJ, Hughes KJD, RJ. Bowyer. 2003. Diagnostic Protocol for Organism Harmful to Plants. Sand Hutton (UK): YO41 1LZ.

Irena G, Jurate R, Mindaugas D, Rimantas S, Zenonas D, Skaidre S. 2013. The effect of strong microwave electric field on: wheat (Triticum aestivum L.) seed germination and sanitation. Zemdirbyste Agric. 100(2):185-190. DOI: https://doi. org/10.13080/z-a.2013.100.024.

Khan MA, MA Shakoor, N Javed, MJ Arif, M Hussain. 2010. A disease predictive model for karnal bunt of wheat based on two years environmental conditions. Pak J Phytopathol. 22(2): 108-112.

Lei Zhu, Qu Haixia, Huang Yun. 2012. Effect of heat treatment on Tilletia caries in wheat. 
[Abstrak]. Journal Anhui Agricultural Science Bulletin. 13(2012):13. Tersedia pada: http://en.cnki.com.cn/Article_en/ CJFDTotal-AHNB201213013.htm. [diakses 5 Feb 2015].

Majumder D, Rajesh T, Suting EG, Debbarma A. 2013. Detection of seed borne pathogens in wheat: recent trends. AJCS. 7(4):500507.

Mansoori B. 2015. Biology and epidemiology of Tilletia indica inducing Karnal bunt (partial bunt) of wheat (Triticium aestivum). IndPhytopathol. 68(1):39-41. DOI: https:// doi.org/10.1094/Phyto-76-487.

Matyac CA, Kommedahl T. 1985. Survival of teliospores of Sphacelotheca reiliana in soil. Phytopathology. 76(5):487-490.

Mitra M. 1931. A new bunt of wheat in India. Ann Appl Biol. 18:178-179. DOI: https://doi.org/10.1111/j.1744-7348.1931. tb02294.x.

[PERMENTAN] Peraturan Menteri Pertanian Republik Indonesia. 2015. Peraturan Menteri Pertanian Republik Indonesia Nomor 51/Permentan/KR.010/9/2015 tentang Perubahan atas Peraturan Menteri Pertanian Nomor 93/Permentan/ OT.140/12/2011 tentang Jenis Organisme Pengganggu Tumbuhan Karantina.
Piepenbring M, Bauer R, Oberwinkler F. 1998. Teliospore of smut fungi general aspects of teliospore walls and sporogenesis. Protoplasma. 204:155-169. DOI: https:// doi.org/10.1007/BF01280322.

Sharma R, R Kumari. 2017. Karnal bunt disease of wheat study from Jhunjhunu, Rajasthan. Int J Adv Ideas Innov Technol. 3(2):834-835.

Stein JM, HW Maples, CM Rush. 2005. Epidemiology of Tilletia indica teliospores in regulated wheat fields in Texas. Plant Dis. $89(8): 828-833$ DOI: https://doi. org/10.1094/PD-89-0828.

Waldow F, Jahn M. 2007. Investigation in the regulation of common bunt (Tilletia tritici) of winter wheat with regard to threshold values, cultivar susceptibility and nonchemical protection measures. J Plant Dis Protec. 114 (6):269-275. DOI: https://doi. org/10.1007/BF03356228.

Warham EJ. 1986. Karnal bunt disease of wheat: a literature review. Trop Pest Management. 32:229-242. DOI: https:// doi.org/10.1080/09670878609371068.

Wei-Chuan Z, Gui-ming Z. 2010. Prediction of potential epidemiological areas in China prone to karnal bunt of wheat. J Plant Pathol. 92(2):363-373. 